\title{
PERANAN SISTEM REPONG DAMAR TERHADAP PENDAPATAN, ASUPAN MAKAN DAN STATUS GIZI BALITA: STUDI KASUS DI DESA PAHMUNGAN KECAMATAN PESISIR TENGAH KABUPATEN PESISIR BARAT
}

\author{
(ROLE OF DAMAR AGROFOREST SYSTEM TOWARDS INCOME HEALTH \\ STATUS AND NUTRITIONAL STATUS OF TODDLERS: A CASE STUDY IN \\ PAHMUNGAN SUB-DISTRICT CENTRAL PESISIR DISTRICT WEST PESISIR)
}

\author{
Desmayanti Eka Saputri, Samsul Bakri, dan Reni Zuraida \\ Jurusan Kehutanan Fakultas Pertanian Universitas Lampung \\ J1. Soemantri Brojonegoro No. 1 Bandar Lampung \\ Email : desmayantieka@gmail.com, Phone : 085381020062
}

\begin{abstract}
ABSTRAK
Kawasan Dengan Tujuan Istimewa atau KDTI (SK Menhut No.47/Kpts-II/1998) hutan adat Repong Damar seluas 29.000 ha yang merupakan best practice dalam manajemen hutan berbasis masyarakat di Provinsi Lampung Bagian Barat belum diketahui tentang kapasitasnya dalam menjamin kebersinambungan pembangunan sumberdaya manusia utamanya yang kritis mulai pada usia balita. Penelitian ini dilakukan mulai bulan Maret-April 2014 di Desa Pahmungan Kecamatan Pesisir Tengah Kabupaten Pesisir Barat. Tujuan dari penilitian ini adalah untuk mengetahui pengaruh simultan antara populasi kepemilikan pohon damar dengan pendapatan, pengeluaran pangan rumah tangga, asupan makan balita, dan status gizi balita. Akuisisi data dilakukan melalui wawancara untuk menjaring data populasi kepemilikan pohon damar [PHN], pendapatan [YI], pengeluaran pangan [YII], asupan makan (food recall) balita sebagai dasar penentuan status gizi balita [YIII] yang dihitung dengan metode antropometri (Kemenkes, 2010), khususnya berat badan menurut tinggi badan (BB/TB). Untuk menguji hipotesis digunakan persamaan simultan 4 tahap. Optimasi parameter menggunakan piranti lunak minitab 16. Simpulan, telah dibuktikan ada tautan yang nyata antara peranan sistem repong damar terhadap pendapatan, status kesehatan, dan status gizi balita. Ditemukan relasi/hubungan nyata antara pendapatan repong damar [Y $\mathrm{Y}_{\mathrm{I}}$ ] $\left[\mathrm{Y}_{\mathrm{I}}\right]_{\mathrm{i}}=-0.1770+0.023150[\mathrm{PHN}]_{\mathrm{i}}$. Selanjutnya secara simultan ditemukan hubungan nyata antara pengeluaran pangan $\left(\mathrm{Y}_{\mathrm{II}}\right)$ dengan $\left[\mathrm{Y}_{\mathrm{II}}\right]$ seperti digambarkan dengan model $\left[\mathrm{Y}_{\mathrm{II}}\right]_{\mathrm{i}}=$ $1.1546+0.438\left[\mathrm{Y}_{\mathrm{I}}\right]$. Lebih lanjut secara simultan ditemukan hubungan nyata antara asupan makan balita $\left[\mathrm{Y}_{\mathrm{III}}\right]$ dengan pengeluaran pangan $\left[\mathrm{Y}_{\mathrm{II}}\right]$ dengan model $\left[\mathrm{Y}_{\mathrm{III}}\right]_{\mathrm{i}}=17.012+3.703$ [Y $\left.\mathrm{Y}_{\mathrm{II}}\right]$.
\end{abstract}

Kata kunci: Repong damar, pendapatan, status kesehatan dan status gizi balita.

\section{ABSTRACT}

Regions Special Purpose or KDTI (Ministry of Forestry decree No.47/Kpts-II/1998) Repong Damar indigenous forest area of 29,000 ha which is a best practice community-based forest management in the western part of Lampung Province yet known about its capacity to ensure the sustainability of human resource development primarily critical starting at the age of five or its called toddlers. This study was doing from March to April 2014 in the village of Pahmungan District of the West Pesisir. The purpose of this research is: Knowing the linkage between population and income damar tree tenure, household food expenditure, protein intake toddlers, health status and nutritional status of toddlers. Data acquisition was done 
through interviews to collect data ownership damar tree population, income, food expenditure, health status and food intake (food recall) as the basis for determining the toddler nutritional status of children is calculated by the method of anthropometry (Ministry of Health, 2010). Parameter optimization using the software Minitab 16. The conclusions has proven there is a real link between the role of damar agroforest system to income, health status, and nutritional status of toddlers. Found relations or real relationship between income of damar agroforest $\left[Y_{I}\right]$ with a population of damar tree with a model $\left[Y_{I}\right] i=-0.1770$ $+0.023150[\mathrm{PHN}] \mathrm{i}$. Furthermore simultaneously discovered the real relationship between food expenditure $\left(Y_{I I}\right)$ with $\left[Y_{I I}\right]$ as illustrated by the model $\left[Y_{I I}\right] i=1.1546+0438\left[Y_{I}\right]$. Further simultaneously discovered the real relationship between protein intake toddlers $\left[Y_{I I I}\right]$ with food expenditure $\left[Y_{I I}\right]$ with the model $\left[Y_{I I I}\right] i=17012+3703\left[Y_{I I}\right]$.

Keyword: Repong damar, income, health status and nutritional status of toddlers.

\section{PENDAHULUAN}

Repong dalam terminologi masyarakat Pesisir Barat adalah sebidang lahan kering yang ditumbuhi beraneka-ragam jenis tanaman produktif dari beragam jenis kayu yang bernilai ekonomis. Disebut Repong Damar karena pohon damar (Shorea javanica) merupakan tegakan yang dominan jumlahnya pada setiap bidang repong (Mulyani, 2008). Merupakan Kawasan Dengan Tujuan Istimewa atau KDTI (SK Menhut No.47/Kpts-II/1998) hutan adat Repong Damar seluas 29.000 ha yang merupakan best practice manajemen hutan berbasis masyarakat. Fakta tersebut cukup membuktikan keberlanjutan sistem budidaya ini dipandang mampu menopang kehidupan sosial ekonomi masyarakat yang bernaung di dalamnya.

Pendapatan yang diperoleh dari Repong Damar khususnya resin pohon damar digunakan untuk menopang kebutuhan hidup seperti, kebutuhan pangan maupun kebutuhan non pangan. Pengeluaran yang digunakan untuk kebutuhan pangan ini sangat menjadi penentu bagi asupan gizi yang seterusnya akan menentukan kesehatan dan produktivitas keluarga petani (Suhardjo, 2005) dan pada akhirnya juga akan menentukan tingkat pengetahuan keluarga petani tersebut tentang sistem budidaya Repong Damar secara lestari. Sehubungan dengan itu, penjaminan kecukupan asupan gizi telah menjadi tema sentral dalam pembangunan kualitas sumberdaya manusia. Bahkan asupan gizi menjadi sangat strategis untuk dimulai sejak dini, terutama ketika masih usia balita (Ismail, 2013). Kelompok umur yang rentan terhadap penyakit-penyakit kekurangan gizi adalah kelompok bayi dan anak balita. Oleh sebab itu, indikator yang paling baik untuk mengukur status gizi masyarakat adalah melalui status gizi balita (Silaen, 2014). Dalam konteks keberlanjutan sistem budidaya Repong Damar telah banyak penelitian yang menjustifikasi tentang sosial, ekonomi, ekologi Repong Damar (Lensary, 2011), biokonservasi satwa dan tumbuhan (Dewi dan Harianto, 2009), dan komposisi tanaman (Putri, 2009).

Keberlanjutan sistem Repong Damar dengan pendapatan yang diperoleh dan jaminan kecukupan gizi masyarakat, belum ditemukan penelitian tentang hal ini terlebih dikhususkan pada balita usia 24-60 bulan yang merupakan salah satu faktor penentu bagi pembangunan manusia (UNDP, 2012). Atas dasar latar belakang masalah yang diuraikan di atas, maka penulis tertarik untuk melakukan penelitian tentang peranan sistem Repong Damar terhadap pendapatan, asupan makan dan status gizi balita di Desa Pahmungan Kecamatan Pesisir Tengah Kabupaten Pesisir Barat. Sebagaimana dapat dicermati pada Gambar 1 di bawah , dalam penelitian ini telah dirunut peranan kepemilikan populasi pohon damar terhadap pendapatan keluarga dari sistem budidaya ini. Selanjutnya, peranan pendapatan ini digunakan untuk menentukan model pengeluaran pangan yang kemudian digunakan untuk 
memodelkan besarnya asupan makan bagi balita. Pada akhirnya, model asupan protein ini digunakan sebagai variabel endogen dalam menentukan model status gizi balita.

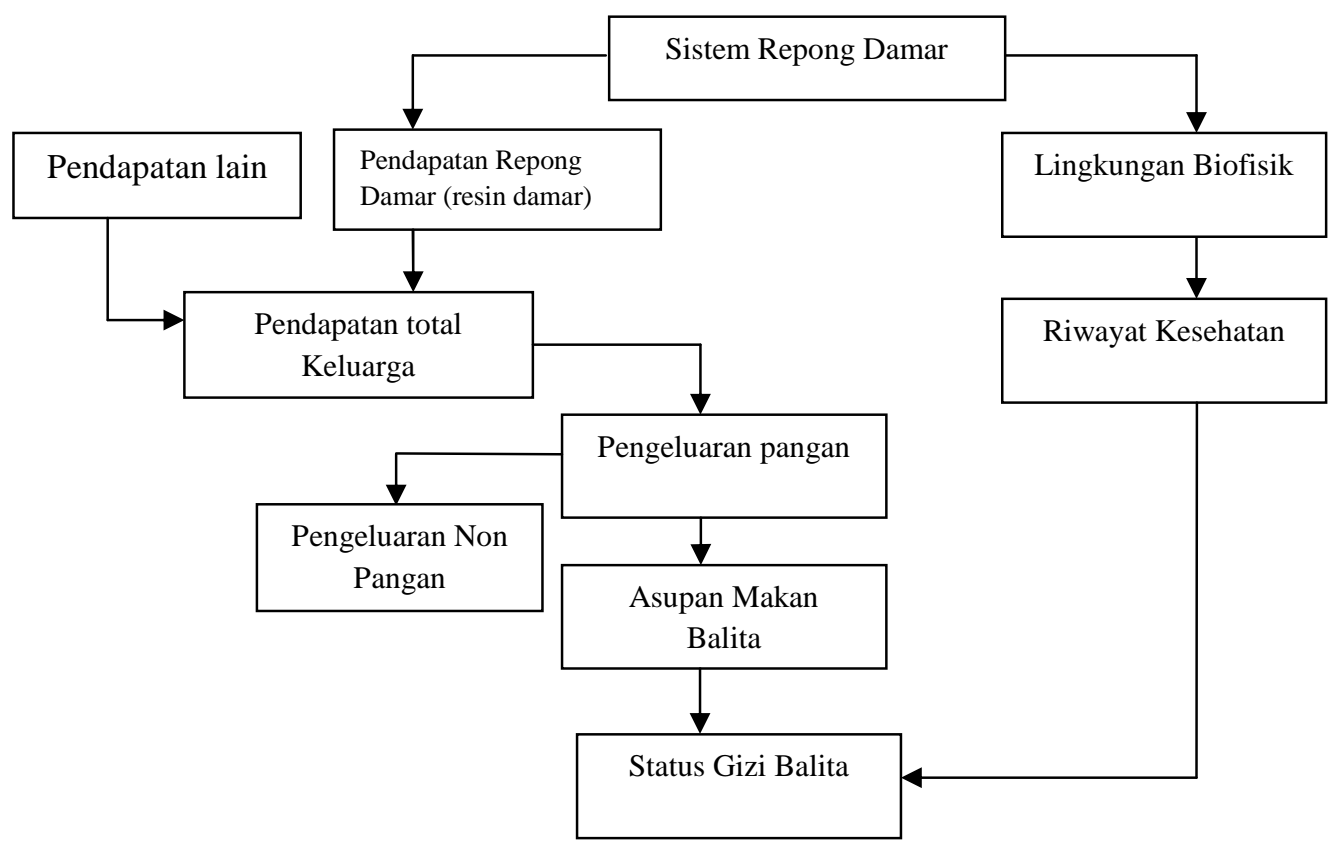

Gambar1. Kerangka Pemikiran Alur Penelitian

\section{METODE PENELITIAN}

\section{Lokasi dan Waktu Penelitian}

Penelitian ini dilaksanakan pada bulan Maret 2014 di Desa Pahmungan Kecamatan Pesisir Tengah Kabupaten Pesisir Barat.

\section{Alat dan Instrumen Penelitian}

Alat dan instrumen yang digunakan adalah timbangan, meteran, kuisioner, kuisioner food recall 24 jam yang dilengkapi dengan identitas balita.

\section{Populasi dan Sampel Penelitian}

Populasi dalam penelitian ini adalah semua balita yang berasal dari keluarga petani Repong Damar pada usia 24-60 bulan yang berjumlah 125 balita dan sampel berjumlah 56 balita.

\section{Model Penelitian}

Penelitian ini menggunakan model persamaan simultan 4 tahap yang meliputi: (1) Pendapatan Repong Damar [Y $\left.\mathrm{Y}_{\mathrm{I}}\right]$ sebagai fungsi dari populasi pohon, (2) Pengeluaran pangan

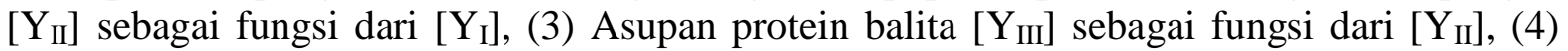
Status gizi balita sebagai fungsi dari asupan protein $\left[\mathrm{Y}_{\mathrm{III}}\right]$. Adapun masing-masing model dapat dirinci (1) $\left[\mathrm{Y}_{\mathrm{I}}\right]_{\mathrm{i}}=\alpha_{0}+\alpha_{1}[\mathrm{PHN}]_{\mathrm{i}}+\mathrm{c}_{\mathrm{i}}$ dimana $[\mathrm{PHN}]$ adalah variabel bebas berupa populasi pohon, $\alpha_{0}$ dan $\alpha_{1}$ merupakan parameter model 1. (2) $\left[\mathrm{Y}_{\mathrm{II}}\right]_{\mathrm{i}}=\beta_{0}+\beta_{1}\left[\mathrm{Y}_{\mathrm{I}}\right]_{\mathrm{i}}+\mathrm{d}_{\mathrm{i}}$ dimana [Y $\left.\mathrm{Y}_{\mathrm{II}}\right]$ adalah pengeluaran pangan pohon, $\beta_{0}$ dan $\beta_{1}$ merupakan parameter model 2. (3) $\left[\mathrm{Y}_{\mathrm{III}}\right]_{\mathrm{i}}=$ $\boldsymbol{\gamma}_{0}+\boldsymbol{\gamma}_{1}\left[\mathrm{Y}_{\mathrm{II}}\right]_{\mathrm{i}}+\mathrm{e}_{\mathrm{i}}$ dimana $\left[\mathrm{Y}_{\mathrm{III}}\right]$ adalah asupan protein balita, $\boldsymbol{\gamma}_{0}$ dan $\boldsymbol{\gamma}_{1}$ merupakan parameter model 3. (4) $\left[\mathrm{Y}_{\mathrm{IV}}\right]_{\mathrm{i}}=e^{-a}+\mathrm{f}_{\mathrm{i}}$ dimana $\left[\mathrm{Y}_{\mathrm{IV}}\right]$ adalah status gizi, dan $e^{-a}$ merupakan parameter model 4. 


\section{Pengumpulan Data}

Data primer diperoleh dari menggunakan metode survei yaitu dengan cara wawancara langsung kepada petani Repong Damar yang memiliki balita usia 24-60 bulan secara pribadi untuk memperoleh informasi tentang pendapatan per bulan dan status gizi balitanya. Untuk memperoleh asupan makanan menggunakan Food recall. Selanjutnya status gizi balita diolah dengan menggunakan parameter antropometri (Kemenkes, 2010).

\section{Analisis Data dan Uji Hipotesis}

Optimasi pendugaan parameter bagi keempat model simultan tersebut di atas akan digunakan dengan piranti lunak Minitab versi 16. Signifikansi keempat model simultan tersebut (goodness of fit test) akan digunakan uji Fisher pada taraf nyata $5 \%$ dan $10 \%$. Sedangkan uji Parameter masing-masing model akan digunakan uji $\mathrm{T}$ pada taraf nyata 5\% dan $10 \%$.

\section{HASIL PEMBAHASAN}

\section{Pendapatan Repong Damar sebagai Fungsi dari Populasi Pohon Damar}

Hasil pemodelan antara pendapatan repong damar $\left[\mathrm{Y}_{\mathrm{I}}\right]$ sebagai fungsi dari populasi kepemilikan pohon damar $[\mathrm{PHN}]$ adalah: $\left[\mathrm{Y}_{\mathrm{I}}\right]_{\mathrm{i}}=-0.1770+0.023150 * *[\mathrm{PHN}]_{\mathrm{i}}$ dengan $\mathrm{R}-$ $\mathrm{Sq}(\operatorname{adj})=63.4 \%$ dan $\mathrm{P}_{\text {value }}=0.000$. Temuan ini memberi makna bahwa pendapatan dari Repong Damar dapat dijelaskan secara cukup baik berdasarkan jumlah populasi pohon damar yang dimiliki oleh setiap kepala keluarga. Dalam hal ini, setiap ada penambahan pemilikan pohon damar 1 batang, maka pendapatan rata-rata keluarga dari sistem budidaya ini meningkat Rp23.150,00/bulan dan peningkatan pendapatan sangat nyata $\left(\mathrm{P}_{\text {value }}=0.000\right)$. Menurut penelitian Lensary (2011) Repong Damar sangat memiliki arti dalam menopang kehidupan masyarakat, karena itu jumlah pohon damar yang ada dalam repong menjadi penentu banyaknya resin damar yang dihasilkan.

\section{Pengeluaran Pangan sebagai fungsi dari Pendapatan Repong Damar}

Hasil pemodelan antara pengeluaran pangan [Y $\left.\mathrm{Y}_{\mathrm{II}}\right]$ sebagai fungsi dari pendapatan Repong Damar $\left[\mathrm{Y}_{\mathrm{I}}\right]$ adalah: $\left[\mathrm{Y}_{\mathrm{II}}\right]_{\mathrm{i}}=1.1546+0.438 * *\left[\mathrm{Y}_{\mathrm{I}}\right]$ dengan $\mathrm{R}-\mathrm{Sq}(\operatorname{adj})=75.8 \%$ dengan $\mathrm{P}_{\text {value }}=0.000$ yang bermakna bahwa setiap ada peningkatan pendapatan dari Repong Damar sebesar Rp1jt/KK/bulan maka pengeluaran pangan meningkat sebesar Rp437.730,00/KK/bulan. Klaim tersebut dapat diajukan mengingat pengeluaran untuk konsumsi pangan dapat diharapkan mampu memberikan peningkatan kesehatan pada umumnya dan pada khususnya untuk pemenuhan kecukupan gizi keluarga, terlebih lagi gizi bagi balita (Suryono, 2007) yang merupakan sumberdaya manusia dalam pembangunan di masa yang akan datang. Akan tetapi, jika pendapatan dari repong damar adalah Rp0 (karena pohon damar ditebang habis) maka rata-rata pengeluaran pangan $=\mathrm{Rp} 1.154 .600,00$ tiap keluarga per bulan. Pengeluaran ini harus disediakan dari sumber lain. Fakta ini memberikan bukti bahwa peran Repong Damar begitu penting bagi investasi dalam pengembangan sumberdaya manusia pedesaan khususnya dalam KDTI di Provinsi Lampung (Saroso, 2013).

\section{Asupan Makan Balita sebagai Fungsi dari Pengeluaran Pangan}

Selanjutnya untuk hasil pemodelan antara asupan makan balita[Y $\left.\mathrm{Y}_{\mathrm{III}}\right]$ sebagai fungsi dari pengeluaran pangan $\left[\mathrm{Y}_{\mathrm{II}}\right]$ adalah: $\left[\mathrm{Y}_{\mathrm{III}}\right]_{\mathrm{i}}=17.012+3.703 * *\left[\mathrm{Y}_{\mathrm{II}}\right]$ dengan $\mathrm{R}-\mathrm{Sq}(\operatorname{adj})=18.1 \%$ dan Pvalue $=0.000$. Hasil tersebut membuktikan bahwa setiap ada peningkatan pengeluaran pangan sebesar Rpljt/KK/bulan maka akan diikuti oleh peningkatan asupan protein pada balitanya rata-rata sebesar 3.7 gram. Argumentasi yang penting untuk diajukan terhadap 
pernyataan tersebut bahwa protein merupakan salah satu kerangka dasar (Soediautama, 2004) bagi setiap sel yang bersifat heterotrof mulai dari protozoa sampai mamalia terlebih sel-sel pada manusia.

\section{Status Gizi Balita di Kawasan Budidaya Repong Damar}

Status gizi adalah keadaan tubuh sebagai akibat konsumsi makanan dan penggunaan zat-zat gizi yang dipengaruhi oleh konsumsi makanan dan penggunaan zat-zat gizi dalam tubuh (Almatsier, 2002). Peranan asupan makanan dan status kesehatan terhadap status gizi balita di kawasan budidaya repong damar disajikan pada Tabel 1 dimana atatus gizi dicerminkan dengan $\mathrm{BB} / \mathrm{TB}$.

Tabel 1. Peranan Asupam makanan dan status kesehatan terhadap Status Gizi Balita di Kawasan budidaya Repong Damar.

\begin{tabular}{lllllll}
\hline Predictor & Coef $\left(\varepsilon_{\mathrm{n}}\right)$ & Simbol & StDev & $\mathrm{Z}$ & $\mathrm{P}$ & OddRatio \\
\hline Const $(1)$ & 17 & $\mathrm{Co}_{1}$ & 26216 & 0.00 & 0.999 & \\
Const $(2)$ & 18 & $\mathrm{Co}_{2}$ & 26216 & 0.00 & 0.999 & \\
Const(3) & 25 & $\mathrm{Co}_{3}$ & 26216 & 0.00 & 0.999 & \\
Energi & $\varepsilon_{1}=-0.0000948$ & $\mathrm{E}$ & 0.0008064 & -0.12 & 0.906 & 1.00 \\
Protein & $\varepsilon_{2}=0.09789$ & $\mathrm{Y}_{\mathrm{III}}$ & 0.05994 & 1.63 & 0.102 & 1.10 \\
Lemak & $\varepsilon_{3}=-0.09883$ & $\mathrm{Lm}$ & 0.04353 & -2.27 & 0.023 & 0.91 \\
Karbohid & $\varepsilon_{4}=0.003027$ & $\mathrm{Kar}$ & 0.001433 & 2.11 & 0.035 & 1.01 \\
Kalsium & $\varepsilon_{5}=0.0001547$ & $\mathrm{Ca}$ & 0.0001706 & 0.91 & 0.364 & 1.00 \\
Fosfor & $\varepsilon_{6}=0.0000626$ & $\mathrm{P}$ & 0.0005879 & 0.11 & 0.915 & 1.00 \\
Besi & $\varepsilon_{7}=0.02384$ & $\mathrm{Fe}$ & 0.09689 & 0.25 & 0.806 & 1.02 \\
Vit. A & $\varepsilon_{8}=0.007735$ & $\mathrm{~A}$ & 0.004005 & 1.93 & 0.053 & 1.01 \\
Vit. B & $\varepsilon_{9}=0.10319$ & $\mathrm{~B}$ & 0.03786 & 2.73 & 0.006 & 1.11 \\
Vit. C & $\varepsilon_{10}=-0.17068$ & $\mathrm{C}$ & 0.06299 & -2.71 & 0.007 & 0.84 \\
S.prnpsan & $\varepsilon_{11}=-16$ & $\mathrm{Sp}$ & 26216 & -0.00 & 1.000 & 0.00 \\
Diare & $\varepsilon_{12}=-0.982$ & $\mathrm{Dr}$ & 1.596 & -0.62 & 0.539 & 0.37 \\
Demam & $\varepsilon_{13}=-1.2411$ & $\mathrm{Dm}$ & 0.8879 & -1.40 & 0.162 & 0.29 \\
Flu & $\varepsilon_{14}=-0.3156$ & $\mathrm{Fl}$ & 0.9656 & -0.33 & 0.744 & 0.73 \\
Cacar & $\varepsilon_{15}=-3.954$ & $\mathrm{Cc}$ & 1.384 & -2.86 & 0.004 & 0.02 \\
& & & & & & \\
\hline
\end{tabular}

Log-likelihood $=-34.291$

Test that all slopes are zero: $\mathrm{G}=27.815, \mathrm{DF}=15, \mathrm{P}-$ Value $=0.023$

Sebagaimana dapat dicermati pada Tabel 1 bahwa status gizi balita di kawasan budidaya repong damar ini secara baik dapat dijelaskan oleh 15 variabel seperti yang dispesifikasikan dalam tabel tersebut. Klaim ini dapat ditunjukkan oleh uji Gald yang sangat besar 27.815 dengan Pvalue $=0.023$ (nyata). Namun demikian, hanya sebanyak 6 variabel yang pengaruhnya nyata atau sangat nyata pada taraf $1-10 \%$. Adapun peranan komponen zat gizi makro, vitamin_mineral dan status kesehatan terhadap status gizi balita di kawasan ini diuraikan pada bagian berikut ini.

a. Peranan Komponen Zat Gizi Makro terhadap status gizi balita

Kelompok zat gizi makro adalah protein, lemak, karbohidrat, dan energi. Sebagaimana dapat dicermati pada Tabel 1, asupan protein mempunyai peran positif $\left(\varepsilon_{1}=0.09789\right)$ dan berpengaruh nyata $\left(\mathrm{P}_{\text {value }}=0.1\right)$ terhadap status gizi balita dengan Odd Ratio=1.1. Angka ini memberi makna jika asupan protein rata-rata bagi balita ditingkatkan sebesar 1gram maka status gizi balita meningkat menjadi 1.1 kali semula. Makna lebih lanjut bahwa asupan protein bagi balita di kawasan budidaya ini masih penting untuk terus ditingkatkan. 
Sebagaimana telah dijelaskan dalam penelitian Suharyanto (2011) bahwa dalam tubuh manusia senyawa protein mempunyai peranan yang sangat esensial bukan hanya sebagai kerangka dasar bagi sel-sel penyusun jaringan tubuh tetapi pada puncaknya adalah bagi penyusun sel-sel dalam jaringan otak.

Berbeda peranannya dengan protein, asupan lemak berpengaruh negatif $\left(\varepsilon_{2}=-0.09883\right)$ terhadap status gizi balita. Sebagaimana dapat dicermati pada Tabel 1 bahwa pengaruh negatif ini bersifat nyata $\left(\mathrm{P}_{\text {value }}=0.023\right)$ dimana setiap ada peningkatan asupan lemak rata-rata sebesar 1 gram maka status gizi balita akan menurun menjadi 0.91kali semula (Odd Ratio= 0.91). Sebagian besar lemak dalam tubuh adalah senyawa trigliserida yang memiliki fungsi sebagai penyedia cadangan energi bagi tubuh, isolator, pelindung organ, dan menyediakan asam-asam lemak esensial (Mahan, 2008). Dalam hal lain, balita yang kelebihan lemak dapat memiliki status gizi yang tidak lebih baik dari balita dengan lemak yang cukup (Silaen, 2014).

Sebagaimana halnya dengan protein, karbohidrat berperan positif $\left(\varepsilon_{3}=0.003027\right)$ nyata $\left(\mathrm{P}_{\text {value }}=0.035\right)$ terhadap status gizi balita. Dalam penelitian ini ditemukan bahwa setiap ada peningkatan asupan karbohidrat per gam maka status gizi balita meningkat menjadi 1.01 dari semula. Temuan ini dapat difahami mengingat karbohidrat (terutama serat) ini berperan penting dalam proses pencernaan (Rochsitasari, 2013).

Sama halnya dengan lemak, energi berpengaruh negatif $\left(\varepsilon_{4}=-0.0000948\right)$ terhadap status gizi balita, sebagaimana dapat dicermati pada Tabel 1 pengaruh negatif ini bersifat tidak nyata $\left(\mathrm{P}_{\text {value }}=0.906\right)$ dimana setiap ada asupan energi rata-rata sebesar 1 gram maka status gizi balita akan sama dengan semula (Odd Ratio= 1.00). Energi memiliki pengaruh negatif yang bersifat tidak nyata biasanya disebabkan dari asupan makanan yang kurang baik seperti chiki, es, dan permen (Sulistya dan Sunarto, 2013). Hal ini sesuai dengan penelitian Moehji (2003) bahwa konsumsi makan balita dan penyakit infeksi merupakan faktor langsung yang mempengaruhi status gizi.

\section{b. Peranan Komponen Gizi Mikro terhadap Status Gizi Balita}

Baik mineral maupun vitamin dalam sel tubuh mempunyai peran penting dalam hampir semua proses metaboliesme (Sanjaya, 2009). Dalam penelitian ini, telah diintegrasikan 3 macam vitamin (vitamin A, B, dan C) dan 3 jenis mineral (fosfor, kalsium, dan besi) sebagai variabel penjelas dalam model status gizi balita $\left(\mathrm{Y}_{\mathrm{IV}}\right)$. Sebagaimana dapat diperiksa vitamin A mempunyai peran secara positif $\left(\varepsilon_{5}=0.007735\right)$ nyata $\left(\mathrm{P}_{\text {value }} 0.053\right)$ terhadap status gizi balita. Dalam hal ini jika asupan vitamin A meningkat sebesar 1RE maka status gizi balita meningkat menjadi 1.01 kali semula. Selain berperan penting dapat perkembangan sel-sel mata balita, vitamin A sangat berperan dalam perkembangan sistem kekebalan tubuh balita (Almatsier, 2002).

Sebagaimana pada vitamin A, dalam penelitian ini vitamin B dapat diperiksa mempunyai peran secara positif $\left(\varepsilon_{6}=0.10319\right)$ sangat nyata $\left(\mathrm{P}_{\text {value }} 0.006\right)$ terhadap status gizi balita. Dalam hal ini jika asupan vitamin B meningkat sebesar 1mg maka status gizi balita meningkat menjadi 1.11 kali semula. Asupan vitamin B umumnya juga mengandung B1,B6, serta B12 yang disebut juga sebagai vitamin B complex yang penting untuk menunjang metabolisme karbohidrat dan protein, dan juga berperan penting dalam pemeliharaan sistem nerves, pembentukan sel darah yang dapat menyerang bakteri, sistem sel darah merah dan untuk menciptakan kekebalan tubuh balita (Nasution, 2013). Sama dengan vitamin A dan B, dalam penelitian ini vitamin $C$ dapat diperiksa mempunyai peran secara negatif $\left(\varepsilon_{7}=-0.17068\right)$ sangat nyata $\left(\mathrm{P}_{\text {value }} 0.007\right)$ terhadap status gizi balita. Dalam hal ini jika asupan vitamin $\mathrm{B}$ meningkat sebesar $1 \mathrm{mg}$ maka status gizi balita menurun menjadi 0.84 kali semula. Fakta ini menunjukkan bahwa rata-rata asupan vitamin $\mathrm{C}$ bagi balita di kawasan budidaya ini telah mencukupi bahkan cenderung kelebihan sehingga jika asupan vitamin ini ditingkatkan maka 
pada akhirnya dapat menurunkan status gizi balita. Selain itu, asupan vitamin $\mathrm{C}$ berlebih dapat mengganggu metabolisme sel seperti dalam penyerapan zat besi (Kemenkes, 2012).

Sebagaimana dapat dicermati dalam Tabel 1 bahwa asupan rata-rata zat besi di kawasan budidaya repong damar ini mempunyai pengaruh positif $\left(\varepsilon_{8}=0.02384\right)$. Dalam hal ini, setiap ada kenaikan asupan zat besi $1 \mathrm{mg}$ maka status gizi balita meningkat menjadi $1.02 \mathrm{kali}$ semula. Walaupun begitu, kenaikan ini tidak bersifat nyata $\left(\mathrm{P}_{\text {value }}=0.806\right)$. Fenomena kelebihan asupan vitamin $\mathrm{C}$ maupun kelebihan zat besi bagi balita di kawasan budidaya repong damar ini nampaknya dapat mempercepat penyerapan zat besi yang dapat berakibat pada insomnia maupun diare (Sanjaya, 2009). Sedangkan untuk kalsium dan fosfor memiliki pengaruh positif tetapi tidak nyata terhadap status gizi balita. Dari Tabel 1, dapat dijelaskan bahwa kalsium memiliki $\left(\varepsilon_{9}=0.0000626\right)$ dan $\mathrm{P}_{\text {value }}$ yang tidak nyata yaitu $(0.364)$. Sedangkan untuk fosfor $\left(\varepsilon_{10}=0.0000626\right)$ dan $\mathrm{P}_{\text {value }}(0.915)$. Kalsium merupakan mineral yang paling banyak terdapat di dalam tubuh manusia. Sedangkan fosfor merupakan mineral kedua terbanyak dalam tubuh. Sehingga kalsium dan fosfor berfungsi membentuk tulang untuk menyangga tubuh (Alamsyah, 2013).

Uraian di atas telah membuktikan bahwa pendapatan yang diperoleh dari Repong Damar khususnya resin damar mampu menopang pengeluaran pangan masyarakat Desa Pahmungan yang selanjutnya memiliki keterkaitan dengan asupan makan dan status gizi balita.

\section{KESIMPULAN}

Dalam penelitian ini telah dibuktikan adanya pertautan antara peranan sistem repong damar terhadap pendapatan, asupan makan, dan status gizi balita. Ditemukan relasi antara pendapatan repong damar $\left(\mathrm{Y}_{\mathrm{I}}\right)$ dengan jumlah populasi pohon damar. Selanjutnya secara simultan ditemukan hubungan antara pengeluaran pangan $\left(\mathrm{Y}_{\mathrm{II}}\right)$ dengan $\mathrm{Y}_{\mathrm{I}}$ dan hubungan antara asupan makan balita $\left(\mathrm{Y}_{\mathrm{III}}\right)$ dengan pengeluaran pangan $\left(\mathrm{Y}_{\mathrm{II}}\right)$.

\section{DAFTAR PUSTAKA}

Alamsyah, D. 2013. Pemberdayaan Gizi Teori dan Aplikasi. Buku. Nuha Medika. Yogyakarta. 26p.

Almatsier, S. 2002. Prinsip Dasar Ilmu Gizi. Buku. PT. Gramedia Pustaka Utama. Jakarta. $50 \mathrm{p}$.

Dewi, B.S. dan S.P. Harianto. 2009. Biokonservasi Satwa dan Tumbuhan (Jenis dan Peranannya dalam Hutan) Di Pekon Pahmungan Kecamatan Pesisir Tengah lampung Barat. Laporan Penelitian. Universitas Lampung. Bandar Lampung. 5p.

Ismail, T. 2013. Penilaian Status Gizi Balita. Jurnal Kesehatan. 12:1-15.

Kementerian Kesehatan RI. 2010. Standar Antropometri Penilaian Status Gizi Anak. Direktorat Jendral Bina Gizi dan Keseharan Ibu dan Anak. Jakarta.

Lensary, D. 2011. Kinerja Pengelolaan Repong Damar Ditinjau Dari Aspek Ekologi, Sosial Dan Ekonomi. Tesis. Institut Pertanian Bogor. Bogor. 46p.

Mulyani, D. 2008. Studi Pemanfaatan Berbagai Spesies Tumbuhan Berkhasiat Obat oleh Masyarakat di Pekon Pahmungan Kecamatan Pesisir Tengah Lampung Barat. Skripsi. Universitas Lampung. Bandar Lampung. 25p.

Moehji, S. 2003. Ilmu Gizi Penanggulangan Gizi Buruk. Jurnal Kesehatan. 2:1-12.

Nasution, M. 2013. Hubungan Asupan Energi-Protein dengan Status Gizi Balita di Desa Sriwulan. Skripsi. Universitas Diponegoro. Semarang. 35p. 
Putri, M. D. 2009. Proporsi Dan Keanekaragaman Hasil Hutan Di Repong Damar Pekon Pahmungan Krui Lampung Barat. Skripsi. Universitas Lampung. Bandar Lampung. $6 \mathrm{p}$.

Rochitasari, S. 2013. Jenis-Jenis Serat dalam Karbohidrat. Jurnal Kesehatan untuk Anak. 3:1-15.

Saroso, M. 2013. Kehidupan Di Bawah Tegakan Damar. Skripsi. Universitas Sumatera Utara. Medan. 7p.

Silaen, P. 2014. Tingkat Kecukupan Energi Dan Protein Serta Status Gizi Anak Balita Rumah Tangga Miskin Di Blambangan Umpu Kabupaten Way Kanan. Skripsi. Universitas Lampung. Bandar Lampung. 37p.

Soediautama, A. 2004. Ilmu Gizi Untuk Profesi Dan Mahasiswa Jilid III. Buku. Dian Rakyat. Jakarta. 55p.

Suhardjo. 2005. Perencanaan Pangan dan Gizi. Jurnal Gizi dan Pangan. 2:24-40.

Suharyanto. 2011. Kaitan Sosial Ekonomi Keluarga dan Konsumsi Energi Protein dengan Staus Gizi Anak Sekolah di desa Sumber Agung, Kecamatan Banjarejo, Kabupaten Blora. Skripsi. Universitas Diponegoro. Semarang. 61p.

Sulistya, H. Dan Sunarto. 2013. Hubungan Tingkat Asupan Energi dan Protein dengan Kejadian Gizi Kurang Anak Usia 2-5 Tahun. Jurnal Gizi Universitas Muhammadiyah Semarang. 2:25-30.

Suryono. 2007. Pengaruh Pemberian Susu Berkalsium Tinggi Terhadap Kadar Kalsium Darah dan Kepadatan Tulang Remaja Pria. Desertasi. Institut Pertanian Bogor. Bogor. 22p. 